\title{
A ASCENSÃO DE UM TERMO: FASCISMO, NECROPOLÍTICA E O ATUAL CENÁRIO POLÍTICO BRASILEIRO ${ }^{1}$
}

\author{
Yasmin Barros Cortez* \\ Douglas Santos** \\ Liana de Andrade Biar ${ }^{* * *}$
}

\section{Resumo}

O termo fascismo foi alvo de ampla busca nas ferramentas online de pesquisa no ano de 2018 em função das eleições, que criaram uma intensa arena de polarização política. Sua associação se dava especialmente ao candidato que hoje exerce a presidência do país, Jair Bolsonaro. Neste artigo, levantamos hipóteses que sustentam a necessidade de recorrer à palavra fascismo para definir uma figura política, trazendo à tona relações de poder, concretizadas através da biopolítica (FOUCAULT, 1999) e da necropolítica (MBEMBE, 2018), que consolidam práticas de vida e morte e discursos de verdade.

\section{Palavras-chave}

Fascismo. Necropolítica. Poder. Jair Bolsonaro.

\section{1) Precisamos falar sobre fascismo}

Fascismo foi um dos temas mais recorrentes nos debates entre eleitores e nas campanhas de candidatos durante a corrida presidencial de 2018 no Brasil. Prova disso são os indicativos obtidos através do Google Trends ${ }^{2}$ - ferramenta que registra o histórico de pesquisa de uma palavra ou frase ao longo do tempo no Google -, que comprovam um aumento considerável de buscas pela palavra fascismo no Brasil em 2018. O pico de tais buscas se deu na semana de 7 de outubro, dia em que chegou ao fim a primeira etapa das eleições, com a apuração dos votos que garantiu um segundo turno entre os candidatos Fernando Haddad, do PT (Partido dos Trabalhadores), e Jair Messias Bolsonaro, do PSL (Partido Social Liberal). Apesar de haver uma queda posterior, as pesquisas em torno da

\footnotetext{
${ }^{1}$ Esta pesquisa foi realizada no âmbito do PET (Programa de Educação Tutorial) do Departamento de Letras da PUC-Rio, ao longo do ano de 2018 e início de 2019, com apoio financeiro do MEC e tutoria da professora Liana Biar.

* Estudante de graduação em Letras - Licenciatura em Português, Inglês e Literaturas Correspondentes pela Pontifícia Universidade Católica do Rio de Janeiro. Bolsista do PET Letras da PUC-Rio.

${ }^{*}$ Estudante de graduação em Letras - Licenciatura em Português e Literaturas de Língua Portuguesa pela Pontifícia Universidade Católica do Rio de Janeiro. Bolsista do PET Letras da PUC-Rio.

${ }^{* \star *}$ Liana Biar é doutora em Letras pela Pontifícia Universidade Católica do Rio de Janeiro (2012) e atualmente é professora adjunta nessa instituição, atuando na graduação em Letras e no Programa de PósGraduação em Estudos da Linguagem, linha de pesquisa "discurso, vida social e práticas profissionais". ${ }^{2}$ Cf. https://trends.google.com.br/trends/explore?geo=BR\&q=Fascismo. Último acesso: 24/06/2019, às $13 \mathrm{~h} 42$.
} 
palavra apresentam um índice de busca mais elevado em comparação com anos anteriores.

O Google Trends apresenta o registro de buscas dos usuários do Google a partir de 2004. No Brasil, fascismo nunca obteve um índice de procura tão alto quanto entre os meses de setembro e novembro de 2018. Além disso, o Brasil foi o país que mais buscou a palavra fascismo no Google em todo o mundo entre os meses de novembro de 2017 e novembro de 2018, ultrapassando a Itália, país onde surgiu a acepção política do termo. Importante destacar que, em italiano, o registro da palavra dá-se exatamente da mesma forma que em português, o que traz ainda mais relevância para a comparação entre os resultados dos dois países. Ratificando tais percepções, o balanço anual do Google indicou que, no ano de 2018, “O que é fascismo?" foi a pesquisa mais realizada em todo o território brasileiro, na categoria o que é (NOVAES, 2018). Segundo informações do jornal Folha de São Paulo, “em 8 de outubro, dia seguinte ao primeiro turno da eleição, a página a respeito do fascismo foi a mais vista na Wikipédia em português, com 205.844 visitas. Somou, na primeira quinzena deste mês, mais de 1 milhão de visualizações, o maior número desde 2015" (ALMEIDA, 2018).

Semelhante processo deu-se nos Estados Unidos, em 2016, ano da disputa presidencial que elegeu o republicano Donald Trump para o cargo. Naquele ano, fascismo foi vice-campeão em buscas na página online do dicionário Merriam-Webster, perdendo apenas para a palavra surreal, como relata Madeleine Albright (2018, p. 15). Para a autora, "[s] e pensarmos no fascismo como uma ferida do passado que estava quase sarada, colocar Trump na Casa Branca foi como arrancar o curativo e cutucar a cicatriz" (ALMEIDA, 2018, p. 12). Percebe-se, com tais declarações, que o fenômeno, que aqui destacamos pelo viés brasileiro, tem, na verdade, encontrado espaços de similitude ao redor do globo.

No mesmo período em que se registra o pico das pesquisas pelo termo fascismo no Brasil, outro fator, além das eleições, parece ter relevância. No dia 9 de outubro de 2018, o artista Roger Waters, ex-membro da banda Pink Floyd, realiza o primeiro de oito shows de sua passagem por nosso país com a turnê $U s+$ Them. Neste, fez expressa referência à necessidade de se resistir ao que ele chama de neofascismo, nomeando alguns líderes políticos que representam o retorno de ideologias ditatoriais do século XX. Na lista, entre os nomes de Donald Trump, Viktor Orbán, Marie Le Pen, Sebastian Kurz, Nigel Farage, Jarosław Kaczyński e Vladimir Putin, está o do então presidenciável brasileiro Jair Bolsonaro. 
Roger Waters, apesar de fomentar as relações entre o conceito e o presidente eleito, não foi o responsável por inaugurar tal vínculo. Bolsonaro, com suas propostas, posicionamentos e falas, parece já haver tornado possível tal adjetivação - principalmente por parte de seus opositores - muito antes de sequer lançar-se à presidência do país. Com uma vida política de três décadas (seu primeiro cargo foi como vereador do Rio de Janeiro, em 1989), encontrou, especialmente nos últimos oito anos, espaço para intensas repercussões - tanto positivas, quanto negativas - de suas falas entre a população e a grande mídia ${ }^{3}$.

É notório que o fascismo se tornou um tema de intensa discussão em nosso país, mas o alto número de pesquisas sobre a palavra nos informa que o brasileiro vem buscando compreender melhor os significados que comporta. Para dialogar com esta questão, este trabalho se propõe a trazer à tona alguns autores, promovendo uma discussão quanto ao uso do termo, de sua relação com a noção foucaultiana de poder $(1979 ; 1999)$ e da configuração da necropolítica de Achille Mbembe (2018) no contexto político brasileiro contemporâneo. Conectamos tais discussões teóricas a falas do atual presidente Jair Bolsonaro e a situações envolvendo alguns de seus aliados, como o governador do Rio de Janeiro Wilson Witzel, objetivando fomentar a discussão a respeito da prática de recorrer ao conceito de fascismo para fazer referência a tais figuras políticas.

\section{2) Afinal, o que é fascismo?}

O termo fascismo teve ampla e variada acepção ao longo de sua trajetória. Seu primeiro uso político surge para caracterizar o partido inaugurado por Benito Mussolini, na Itália, em 1921 - o Partido Nacional Fascista. O regime implantado por este partido após sua chegada ao poder, em 1922, tem como marca, principalmente, seu aspecto

\footnotetext{
${ }^{3} \mathrm{Cf}$. "Bolsonaro critica 'kit gay' e diz querer 'mudar alguma coisa na Câmara'." http://g1.globo.com/politica/noticia/2011/02/bolsonaro-critica-kit-gay-e-diz-querer-mudar-alguma-coisana-camara.html. Último acesso em: 25/02/2019, às 23h41. | "Bolsonaro diz na TV que seus filhos não 'correm risco' de namorar negras ou virar gays porque foram 'muito bem educados'." https://oglobo.globo.com/politica/bolsonaro-diz-na-tv-que-seus-filhos-nao-correm-risco-de-namorarnegras-ou-virar-gays-porque-foram-muito-bem-educados-2804755. Último acesso em: 25/02/2019, às 23h41. | "Bolsonaro: 'prefiro filho morte em acidente a um filho homossexual'." https://www.terra.com.br/noticias/brasil/bolsonaro-prefiro-filho-morto-em-acidente-a-umhomossexual,cf89cc00a90ea310VgnCLD200000bbcceb0aRCRD.html. Último acesso em: 25/02/2019, às 23h42. "Jair Bolsonaro repete insulto a deputada Maria do Rosário: 'só não te estupro porque você não merece'." https://extra.globo.com/noticias/brasil/jair-bolsonaro-repete-insulto-deputada-maria-do-rosarioso-nao-te-estupro-porque-voce-nao-merece-14781338.html. Último acesso em: 25/02/2019, às 23h42.
} 
autoritário. Entretanto, já à época de seu surgimento seria difícil definir com firmeza quais eram, afinal, os objetivos ou as premissas de um partido fascista. Como destaca Madeleine Albright (2018), em seu best-seller Fascismo: Um alerta:

[o]s fascistas haviam desenvolvido longas listas de metas, mas não tinham um manifesto ou bíblia. Alguns dos entusiastas do partido incipiente o viam como uma forma de resgatar o capitalismo e o catolicismo das hordas leninistas; para outros, seu significado era a defesa da tradição e da monarquia. Para muitos, era a chance de restituir a glória à Itália; e para um número razoável, significava um ganha-pão e um sinal verde para espancamentos (ALBRIGHT; WOODWARD, 2018, p. 28-29).

Por aglutinar tantos interesses e, especialmente, tantas expectativas e esperanças, muito rapidamente o regime fascista começa a adquirir os mais diversos aspectos e cisões não tardam a aparecer. Ao ampliar-se rumo a outros territórios, podendo ser bastante semelhante à sua semente - como são o regime de Francisco Franco, na Espanha, e de António Salazar, em Portugal - ou ganhar características inteiramente novas - como é o caso do nazismo, na Alemanha de Adolf Hitler - ainda mais desfigurações começam a se aglutinar.

Umberto Eco chama atenção para o fato de que o fascismo, apesar de ter sido uma ditadura, não foi completamente totalitário, "pela debilidade filosófica de sua ideologia. Ao contrário do que se pensa comumente, o fascismo italiano não tinha uma filosofia própria. (...) Mussolini não tinha qualquer filosofia: tinha apenas uma retórica.” (ECO, 2019, p. 27-28). Pela falta de escritos que pudessem demarcar seus limites, o fascismo acaba por tornar-se algo difuso, comportando uma variedade tão grande de ideias e propósitos que, por vezes, chega a ser contraditório em si mesmo. É por isso que seus significados são tão variáveis e adaptáveis: “porque é possível eliminar de um regime fascista um ou mais aspectos, e ele continuará sempre a ser reconhecido como fascista" (ECO, 2019, p. 42-43).

Em suas ocorrências, movimentos de cunho fascista obtiveram normalmente algum grau de clamor público, em face da frustração de classes médias "desvalorizadas por alguma crise econômica ou humilhação política, assustadas pela pressão de grupos sociais subalternos" (ECO, 2019, p. 50). Somente a partir da validação por parte de tais movimentos tem-se o surgimento de uma liderança carismática em que as esperanças populares são depositadas. Esta representatividade lhe é garantida pelas massas, e lhe confere um grau de poder que não se impõe em uma perspectiva hierárquica, mas a partir 
de uma rede de confiança. É assim que o fascismo encontra brechas para se proliferar no campo social e político.

Voltemos agora à questão que nos move aqui, qual seja, explorar as associações entre o presidente eleito, Jair Bolsonaro, e o rótulo do fascista. Factualmente, trata-se de um governo eleito, que tem funcionado com base em instituições representativas, propõe uma economia neoliberal e não tem, ao menos em ações institucionais, perseguido grupos em razão de sua origem étnico-racial, gênero ou sexualidade. Onde mora, então, o alegado fascismo de Bolsonaro e seus simpatizantes?

George Orwell já chamava atenção para o amplo espectro de sentido comportado pelo rótulo de "fascista". O termo pode definir coisas absolutamente diferentes entre si, “de democracia pura a demonismo puro" (ORWELL, 2017, p. 85). Há quem associe o termo à simpatia por Hitler, aos regimes comunistas, a um "movimento de massas" (REICH, 1998, p. 27), a manifestações variadas de preconceito em relação às minorias. O que se vê é que o rótulo transita, aliás, como qualquer rótulo, de contexto em contexto, se estendendo e se contraindo a depender dos jogos de linguagem e das disputas de que participa.

De fato, como pesquisadores de sensibilidade discursiva, nosso intuito aqui não é tentar capturar a essência da palavra. Qualquer tentativa nesse sentido, sabemos, falharia miseravelmente. O sentido é contingente, variável na história, dependente de posições. Mas os signos carregam uma historicidade. E seus usos em diversos contextos, embora possam criar efeitos distintos, estão aparentados uns com os outros, mesmo de formas e em direções muito diferentes.

Para Frederico Finchelstein, autor do livro Do fascismo ao Populismo na História (2019), Bolsonaro é um populista (ele altera o rótulo-mãe), isto é, uma figura política assentada em um regime democrático, não ditatorial, neoliberal e não protecionista, mas de ranço fascista. Segundo o autor, Bolsonaro é, dentre os populistas contemporâneos, aquele mais se aproxima do fascismo ${ }^{4}$. O ranço do fascismo mora em alguns semas que comparecem na gramática política do nosso atual presidente, quais sejam o tratamento de opositores como inimigos, no racismo, no uso da violência, o conservadorismo dos costumes, o ethos da masculinidade belicosa, o patriotismo (FINCHELSTEIN, 2019). Todos esses elementos ressoam a história de usos desse signo, ao mesmo tempo em que comportam novos usos apontando para contextos atuais, mesmo cheios de "choques" e

\footnotetext{
${ }^{4}$ https://brasil.elpais.com/brasil/2019/06/27/cultura/1561664077_032428.html
} 
"contradições": "a palavra está sempre carregada de um conteúdo ou de um sentido ideológico ou vivencial" (BAKHTIN, 1995, p. 95).

\section{3) Fascismo e poder}

Ao tratar de poder, Michel Foucault rompe com a concepção bilateral weberiana que estabelece o poder como uma força que funciona de cima para baixo, alegando que "a noção de repressão é totalmente inadequada para dar conta do que existe justamente de produtor no poder", afinal, se "fosse somente repressivo, se não fizesse outra coisa a não ser dizer não", dificilmente seria obedecido (FOUCAULT, 1979, p. 7-8). Para ele, "[o] que faz com que o poder se mantenha e que seja aceito é simplesmente que ele não pesa só como uma força que diz não, mas que de fato ele permeia, produz coisas, induz ao prazer, forma saber, produz discurso" (1979, p. 7-8). O poder é uma rede: está em todos os lugares e não pode ser tomado enquanto algo palpável, concreto, porque não se trata de uma coisa (FOUCAULT, 1999).

É nas sociedades modernas que o poder deixa de se exercer tão somente na dinâmica soberanos-súditos. A partir dos séculos XVII e XVIII, uma nova mecânica do poder é inaugurada, moldando-o, alterando sua atuação. Segundo Foucault, esta nova mecânica do poder "incide primeiro sobre os corpos e sobre o que eles fazem, mais do que sobre a terra e sobre o seu produto" (1999, p. 42). Em seus estudos, as novas configurações de poder são observadas a partir das regras do direito e das verdades que ele produz, sendo estas postas como as duas extremidades do poder, formando com ele uma tríplice. Para ele, estamos igualmente submetidos aos efeitos da produção de verdade, de cuja existência depende a manutenção do poder, e às regras do direito, às normas que são impostas.

Até o século XVII, era a teoria da soberania que entrava em ação, uma forma de poder centrada na figura de um soberano que se apropriava dos bens e da riqueza (FOUCAULT, 1999, p. 43). A burguesia europeia esculpe um novo tipo de poder, focado não mais na monarquia e em seus desejos, mas sim, nas relações econômicas, no capital, implementando um paradigma que reorganiza o funcionamento e a metodologia do poder. Esse poder é alheio a soberanias, regula corpos e indica que todo indivíduo é, por consequência, "um efeito do poder e é, ao mesmo tempo na mesma medida em que é um efeito seu, seu intermediário: o poder transita pelo indivíduo que ele constituiu" (FOUCAULT, 1999, p. 35). O nomeado poder disciplinar: 
[é] um tipo de poder que se exerce continuamente por vigilância e não de forma descontínua por sistemas de tributos e de obrigações crônicas. É um tipo de poder que pressupõe muito mais uma trama cerrada de coerções materiais do que a existência de um soberano, e define uma nova economia de poder cujo princípio é o de que se deve ao mesmo tempo fazer que cresçam as forças sujeitadas e a força e a eficácia daquilo que as sujeita (FOUCAULT, 1999, p. 42).

O poder disciplinar surge, então, de interesses da burguesia em ascender socialmente enquanto potência estatal, pois "quanto mais forças de trabalho houvesse, mais plena e corretamente o sistema da produção capitalista poderia funcionar" (FOUCAULT, 1999, p. 37). Esta inaugurada concepção de poder, para a qual Foucault toma como objeto de análise a regulamentação dos corpos e também da morte, acontece via processos mascarados, micromecanicamente. Dentro de pequenas ações do Estado, há um interesse velado que o favorece macroestruturalmente: os mecanismos de exclusão, a aparelhagem da vigilância, a medicalização da sexualidade, da loucura e da delinquência, a título de exemplo. Logo,

[a] burguesia não se interessa pelos loucos, mas pelo poder que incide sobre os loucos, a burguesia não se interessa pela sexualidade da criança, mas pelo sistema de poder que controla a sexualidade da criança. A burguesia não dá a menor importância aos delinquentes, à punição ou à reinserção deles, que não têm economicamente muito interesse. Em compensação, do conjunto de mecanismos pelos quais o delinquente é controlado, seguido, punido, reformado, resulta, para a burguesia, um interesse que funciona no interior do sistema econômicopolítico geral. (FOUCAULT, 1999, p. 39)

Junto ao novo poder, emerge com ele uma nova tecnologia: a biopolítica. "A soberania fazia morrer e deixava viver. E eis que agora aparece um poder [...] que consiste ao contrário, em fazer viver e deixar morrer" (FOUCAULT, 1999, p. 294). A biopolítica é um direito que se instala, baseado no direito de fazer viver e de deixar morrer, e expressa-se em "um conjunto de processos como a proporção dos nascimentos e dos óbitos, a taxa de reprodução, a fecundidade de uma população, etc" (1999, p. 290).

Em Necropolítica (2003), ao retomar o conceito de biopolítica inaugurado por Michel Foucault (1975-76), Achille Mbembe atribui à soberania não só o poder da vida, mas também, o poder da morte, afirmando que "a expressão máxima da soberania reside, em grande medida, no poder e na capacidade de ditar quem pode viver e quem deve morrer" (MBEMBE, 2018, p. 5). Assim como Foucault, compreende que o exercício do 
poder se dá através do controle da mortalidade e da definição da vida como implantação e manifestação de poder (MBEMBE, 2018), mas faz sua análise de outra ótica, a partir da qual formula seu conceito de necropolítica: a política da morte. Mbembe dá ênfase ao grupo que não é atendido pela biopolítica e, por conseguinte, é deixado para morrer.

A soberania de que fala Mbembe atua pela instrumentalização da existência e pela destruição material de corpos e populações (2018, p. 10-11), agindo como um espaço em que a morte é plenamente praticada a partir de um campo político. Soberania, então, passa a representar "a capacidade de definir quem importa e quem não importa, quem é 'descartável' e quem não é” (2018, p. 41), não correspondendo mais a um indivíduo único dotado de um poder que beirava o material.

Onde exista uma sociedade que se organize politicamente de forma estrutural, há, intrinsecamente, mecanismos que atuam em favor de uma necropolítica, ainda que estes não sejam necessariamente perceptíveis, nem precisam ser facilmente conectáveis ao Estado para que estejam engendrados em tal configuração. Mbembe evoca o fato de que, hoje, o direito de matar não é monopólio do Estado, e que o exército regular não é o único meio de executar a função de morte: “[m]ilícias urbanas, exércitos privados, exércitos de senhores regionais, segurança privada e exércitos de Estado proclamam, todos, o direito de exercer violência ou matar" (MBEMBE, 2018, p. 53).

Mbembe chama atenção para uma importante observação feita por Foucault em seus estudos em torno da biopolítica: em determinado momento, se torna evidente que "[n]azismo e stalinismo não [fizeram] mais do que ampliar uma série de mecanismos que já existiam nas formações sociais e políticas da Europa Ocidental” (2018, p. 32). As ações adotadas por regimes fascistas aprimoram tecnologias e técnicas de morte que sempre estiveram presentes no polo social. De tal forma, o fascismo se relaciona diretamente com a necropolítica - ainda que dentro de um ambiente pretensamente democrático -, pois, através dele, encontra novas formas de se atualizar e aprimorar sua engenharia, uma vez que suas “inovações nas tecnologias de assassinato visam não só 'civilizar' as maneiras de matar, mas também eliminar um grande número de vítimas em um espaço relativamente curto de tempo" (2018, p. 22). Campos de concentração e de trabalho do regime nazista e o desenvolvimento das forças bélicas tornam a política de morte ainda mais eficaz, uma vez que "[m]ecanizada, a execução em série transformou-se em um procedimento puramente técnico, impessoal, silencioso e rápido” (2018, p. 21).

A morte é temida em dados contextos, mas não por todos; apenas por aqueles que se veem reféns de uma tirania que delega seus corpos ao extermínio. Estaria, então, o 
poder deixando de ser o direito de fazer viver e se tornando mais o direito de fazer morrer? Estaria a teoria da soberania encontrando espaço para novamente expandir-se? Com isso, atualmente, a pergunta que devemos postular não é "quais vidas importam?", mas sim, “quais vidas não importam?”. Quais vidas são deixadas de lado e não são atendidas pela biopolítica, mas sim pela necropolítica, que atua diretamente nos corpos que parecem não fornecer benefícios ao Estado e à burguesia?

\section{4) Fascismo e poder: o mito}

Devido à perceptível acentuação das polarizações de conflitos políticos, a partir da qual retorna ao cotidiano a necessidade de um olhar atento e minucioso às configurações do fascismo, precisamos traçar o paralelo inevitável com o momento histórico no qual nos encontramos, em que o presidente eleito não só é taxado de fascista por parte da população civil e dos parlamentares, como também não se defende do rótulo que recebe. Ao longo de sua carreira política, Jair Bolsonaro deu inúmeras declarações que entram em choque direto com os ideais democráticos e ferem os direitos humanos, atacando grupos marginalizados e minoritários e, por vezes, defendendo até mesmo a morte de parcelas da população das quais discorda ideologicamente. Apesar de sempre tentar amenizar o sentido das polêmicas que circundam muitas de suas falas, alegando serem apenas "piadas", seu discurso segue oferecendo espaço a cada vez mais manifestações similares, que, por algum tempo, sentiam-se menos autorizadas.

A partir de agora, nos debruçaremos sobre discursos enunciados por Bolsonaro ao longo de sua trajetória ascendente recente. Não prometemos para as próximas linhas uma análise técnica, comprometida com categorias analíticas de quaisquer das correntes abrigadas pelo termo guarda-chuva "análise de discurso", embora uma sensibilidade dessa natureza esteja presente numa tentativa de estabelecer relações indexicais entre o discurso, os embates de que ele é parte e as posições sócio-históricas que ele mobiliza.

Também não oferecemos rigor metodológico na composição e organização do corpus. Este é um texto ensaístico; uma tentativa inicial e exploratória de fazer sentido de nossas próprias "vertigens" . Cobrimos um período que vai desde a atuação de Bolsonaro na câmara dos deputados até os primeiros meses de seu governo na presidência da

\footnotetext{
${ }^{5}$ Fazemos aqui referência ao recém-lançado documentário de Petra Costa, "Democracia em Vertigem".
} 
república ${ }^{6}$. Nosso critério de seleção dos excertos se baseou na ampla repercussão dessas falas na mídia oficial e nas redes sociais, algumas delas responsáveis ou pela celebrização de sua marca junto a seus eleitores - que a ele tratam de "mito" -, ou pela reação contundente de seus opositores - destacadamente o movimento "Ele Não", liderado por mulheres em todo o país. Todas as versões audiovisuais dos excertos aqui transcritos estão disponíveis na rede. Essa é uma coleção montada por cidadãos estarrecidos.

Em entrevista ao The Noite, programa vinculado ao SBT apresentado pelo comediante Danilo Gentili, em março de 2017, Jair Bolsonaro retomou uma de suas falas mais polêmicas, emitida pela primeira vez em uma entrevista dada na Câmara dos Deputados, em $2015^{7}$, na qual incita o combate da violência com mais violência. No vídeo $^{8}$, Bolsonaro afirma:

Jair Bolsonaro: A violência, prezado Danilo, se combate com violência. Se o vagabundo tá com uma 380, você tem que tá com um fuzil. Se ele tá com um fuzil, você tem que tá com uma bazuca ou com um tanque de guerra. Não é com beijinho, paz e amor.

Ao promover a luta contra a violência com mais violência, Bolsonaro se coloca como o porta voz de um discurso que instaura e promove o embate, o enfrentamento, a guerra. De tal forma, Bolsonaro cria toda uma mítica em torno de uma guerra que está para acontecer, preparando solo para uma batalha decisiva que precisa ser vencida, uma vez que os inimigos se põem a ameaçá-lo. Foucault já alertava para não se poder "chegar ao termo da guerra por algo como uma reconciliação ou uma pacificação" (FOUCAULT, 1999, p. 60). Portanto, é através do combate que Bolsonaro reclama os direitos do povo a que defende, que são, na verdade, seus próprios direitos, que passam a ser públicos quando encontram indivíduos que com eles simpatizam, pois a política também consiste em "um projeto de autonomia e a [sua] realização de acordo em uma coletividade mediante comunicação e reconhecimento” (MBEMBE, 2018, p. 9). É importante dar atenção a esta fala de Bolsonaro porque:

[a] lei não nasce da natureza, junto das fontes frequentadas pelos primeiros pastores; a lei nasce das batalhas reais, das vitórias, dos

\footnotetext{
${ }^{6}$ No momento em que este artigo é escrito, Jair Bolsonaro soma exatos 6 meses de seu mandato iniciado em janeiro de 2019.

7 Cf. "Jair Bolsonaro defende que a PM mate mais no Brasil: 'violência se combate com violência'." https://www.huffpostbrasil.com/2015/10/05/jair-bolsonaro-defende-que-a-pm-mate-mais-no-brasilviolencia_a_21690502/. Último acesso em: 25/02/2019, às $23 \mathrm{~h} 43$.

8 “Jair Bolsonaro - Violência se combate com violência". https://youtu.be/obMDEvqcY3s. Último acesso em: 25/02/2019, às 23h36.
} 
massacres, das conquistas que têm sua data e seu heróis de horror; a lei nasce das cidades incendiadas, das terras devastadas; ela nasce com os famosos inocentes que agonizam no dia que está amanhecendo. (FOUCAULT, 1999, p. 58)

É pelo massacre que se chega à vitória; uma vez vencedor, é possível implementar novos códigos de conduta, produzir novos discursos de verdade através do direito que regulamenta as leis. Estas, ao contrário do que se costuma pensar, não são sinônimo de pacificação, "pois, sob a lei, a guerra continua a fazer estragos no interior de todos os mecanismos de poder, mesmo os mais regulares" (MBEMBE, 2018, p. 59), continuando a proferir efeitos de devastação.

Em fevereiro de 2017, durante um evento de sua campanha eleitoral em Campina Grande, na Paraíba, Bolsonaro promove mais um discurso que dialoga diretamente com o do massacre, complementando-o. O discurso exibido no vídeo ${ }^{9}$ tem como intenção a promoção do terror, afirmando que não haveria espaço, em seu governo, para as minorias:

Jair Bolsonaro: Vamos fazer um país para as maiorias, as minorias têm que ser curvar às maiorias. As leis devem existir para defender as maiorias, as minorias se adequam ou simplesmente desaparecem.

Não compactuar com sua forma de gerir o país coloca automaticamente o indivíduo numa zona de perigo, principalmente após sua eleição, quando fica comprovada a vontade da maioria; vencer um processo democrático reflete justamente o desejo do grupo que computa o maior número de votos nas urnas. Contudo, Madeleine Albright destaca que:

[n]uma verdadeira democracia, os líderes respeitam a vontade da maioria e também os direitos da minoria - não adianta olhar só para um lado. Isso significa que as proteções constitucionais ao indivíduo precisam ser defendidas, mesmo quando tornarem-se inconvenientes para o partido então no poder. (ALBRIGHT; WOODWARD, 2018, p. 116)

Bolsonaro, entretanto, não faz questão de esconder em suas declarações que pretende a garantia de direitos de uma parcela, enquanto tira de outras. Outro exemplo é uma declaração feita em uma palestra para a comunidade judaica no Clube Hebraica, Rio

\footnotetext{
9 Cf. "Jair Bolsonaro diz que a minoria tem que se adequar a maioria 10/02/17".
} https://youtu.be/BCkEwP8TeZY. Último acesso em: 25/02/2019, às 23 h35. 
de Janeiro, em 03/04/2017, que demonstra seus propósitos de revogar direitos adquiridos pelos quilombolas ${ }^{10}$ :

Jair Bolsonaro: Eu fui num quilombola [sic] em Eldorado Paulista. Olha, o afrodescendente mais leve lá pesava sete arrobas. Não fazem nada! Eu acho que nem pra procriador serve mais. Mais de $R \$ 1$ bilhão por ano é gasto com eles.

Incomodado com as demarcações territoriais que garantem aos quilombolas propriedade das terras que habitam, Bolsonaro os reduz a corpos vazios, que não têm utilidade alguma ao Estado, nem mesmo para fornecer o que a biopolítica preza para exercer seu funcionamento em uma sociedade: a vida. Segundo pesquisas recentes, mais de 230 territórios quilombolas têm reconhecimento ameaçado pelo governo ${ }^{11}$, o que nos faz compreender a fala de Bolsonaro como extremamente perigosa e como parte de uma política que se escora em ideais escravocratas, que se tornam ainda mais literais quando $\mathrm{o}$ vemos ameaçando o maior direito garantido às comunidades quilombolas em uma ainda parca tentativa de reparação histórica com as populações africanas aqui escravizadas, "uma característica que define tanto os Estados escravistas quanto os regimes coloniais contemporâneos" (MBEMBE, 2018, p. 68). A violência e a agressividade de seus discursos contra as populações minoritárias se tornam "um componente da etiqueta, como dar chicotadas ou tirar a vida do escravo: um capricho ou um ato de pura destruição visando incutir o terror" (2018, p. 29). As minorias continuam a sofrer com a desterritorialização e violência proferida a seus corpos desumanizados por um discurso racista que promove a restauração de táticas coloniais de extermínio do povo negro.

Em outro vídeo ${ }^{12}$, às vésperas do segundo turno, em que disputou a presidência com o candidato Fernando Haddad, do PT, Jair Bolsonaro, então candidato pelo PSL, volta a disseminar o terror contra os marginais vermelhos, modo como apelida seus opositores. Importante ressaltar que o PT, bem como grande parte dos partidos e movimentos de esquerda, tem como cor representativa o vermelho.

\footnotetext{
${ }^{10} \mathrm{Cf}$. "Negro quilombola não serve nem pra procriar!". https://youtu.be/ks0dgE8jpkw. Último acesso em: 24/06/2019, às $16 \mathrm{~h} 45$.

11 "230 territórios de quilombolas têm reconhecimento ameaçado pelo governo; cunhado de Bolsonaro invadiu quilombo em SP." http://www.ihu.unisinos.br/78-noticias/585856-230-territorios-de-quilombolastem-reconhecimento-ameacado-pelo-governo-cunhado-de-bolsonaro-invadiu-quilombo-em-sp. Último acesso em: 25/02/2019, às 23h44.

${ }^{12} \mathrm{Cf}$. "Bolsonaro diz que marginais vermelhos serão banidos do Brasil". https://youtu.be/6AkDNfmi7zs. Último acesso em: 25/02/2019, às $23 \mathrm{~h} 37$.
} 
Jair Bolsonaro: Perderam ontem, perderam em 2016 e vão perder a semana que vem de novo. Só que a faxina agora será muito mais ampla. Essa turma, se quiser ficar aqui, vai ter que se colocar sob a lei de todos nós, ou vão pra fora ou vão pra cadeia. Esses marginais vermelhos serão banidos de nossa pátria. Nós acreditamos no futuro do nosso Brasil. E juntos, em equipe, construiremos o futuro que nós merecemos.

Ao mencionar que "perderam ontem", Bolsonaro se refere ao resultado do primeiro turno das eleições presidenciais de 2018, que garantiu um segundo entre ele e Fernando Haddad. Já a derrota de 2016 é uma menção ao impeachment da ex-presidenta Dilma Rousseff, que teve seu mandato cassado após aprovação do processo no Senado em 31 de agosto de 2016. Ao dizer "essa turma, se quiser ficar aqui, vai ter que se colocar sob a lei de todos nós", Bolsonaro reforça a implementação de suas leis através do Direito. A "turma" não só englobaria os candidatos do PT, mas também todos aqueles que se alinham ideologicamente ao Partido dos Trabalhadores, o grupo anti-hegemônico. Ao dizer que irá "construir o futuro que nós merecemos", se refere apenas à fatia que cede seu voto a ele, submetendo todos os outros indivíduos a um lugar de não pertencimento, pois "o poder continuamente se refere e apela à exceção, à emergência e a uma noção ficcional de inimigo" (MBEMBE, 2018, p. 17), tornando-os alvos dos efeitos que o poder produz.

Se os efeitos de seus discursos provocam medo e alarmam a população comum que opõe-se ao então candidato, seja pelo viés político, seja por fazer parte das minorias contra as quais ele incita os seus, os efeitos tornam-se ainda mais palpáveis quando afetam diretamente a classe política, dentro da qual, poder-se-ia supor, haveria algum sentimento de estar protegido, pois é para onde facilmente voltam-se os olhos da população. Já no dia 28 de janeiro de 2019, acompanhamos o deputado federal Jean Wyllys, membro do PSOL (Partido Socialismo e Liberdade), eleito três vezes pelo Rio de Janeiro, LGBT, defensor de pautas da causa na Câmara e uma das principais vozes contra Jair Bolsonaro, abrir mão de seu mandato e anunciar sua mudança para outro país, alegando fazê-lo como forma de defender-se das constantes ameaças de morte que recebeu após o candidato do PSL ser eleito presidente ${ }^{13}$.

Ainda mais grave é o caso de Marielle Franco, a ex-vereadora da Câmara do Rio de Janeiro, também pelo PSOL, mulher negra, LGBT e oriunda da favela, que foi brutalmente executada no dia 14 de março de 2018, vítima de 13 tiros disparados contra

\footnotetext{
${ }^{13}$ Cf. "Deputado Jean Wyllys abandona cargo e deixa Brasil após ameaças." https://istoe.com.br/deputado-jean-wyllys-abandona-cargo-e-deixa-brasil-apos-ameacas/ Último acesso em: 25/02/2019, às 23h42.
} 
o veículo em que estava, junto ao motorista, Anderson Pedro Gomes, que também foi atingido e veio a óbito. Quase um ano após o atentado, o crime continua sem solução, mas não sem encontrar ecos que renovem crueldades contra sua memória, como o famoso episódio em que o deputado federal Daniel Silveira e o deputado estadual Rodrigo Amorim, ambos do Rio de Janeiro, quebraram uma placa com o nome da ex-vereadora, em um comício do atual governador do Rio de Janeiro, Wilson Witzel ${ }^{14}$. Tais situações reforçam atos de violência ainda na atmosfera política contra aqueles que seguem promovendo uma tentativa de furar o duro tecido que mantém sempre os mesmos grupos beneficiados pela soberania e pelos efeitos do poder. Mesmo após a veiculação da notícia, não houve punições, nem qualquer tipo de retratação foi emitida.

O supracitado governador Wilson Witzel, do PSC (Partido Social Cristão), que teve uma surpreendente e esmagadora vitória na eleição de 2018, é também eco da linguagem agressiva e direcionada de Jair Bolsonaro. Durante entrevista a repórteres do Globo News em 30 de outubro 2018, após ser eleito governador do Rio de Janeiro no segundo turno, Witzel é questionado sobre uma de suas propostas a serem implementadas ao assumir o posto em 2019: enquanto candidato, prometia o uso de tropas de elite como snipers para "abater criminosos que estejam portando fuzil", a partir de primeiro de janeiro de 2019. O governador diz no vídeo ${ }^{15}$, durante um diálogo com uma das repórteres:

Repórter: Pode vir à cabeça a seguinte hipótese, digamos assim: um cidadão com um fuzil, de costas (tô aqui montando um cenário possível, plausível ou não), de costas, e a possibilidade de um sniper ou de um policial executá-lo sem ele estar representando nenhuma ameaça. Mas como o senhor diz, que isso que o senhor propõe.

Wilson Witzel: Tá de fuzil na mão?

Repórter: Ele tá de fuzil na mão.

Wilson Witzel: Ameaça.

Aliada a esta proposta de Wilson Witzel está a do atual ministro da justiça Sérgio Moro, apresentada em 04 de fevereiro 2019, que prevê redução ou abono de aplicação de

\footnotetext{
14 “É \#FATO que deputados eleitos pelo PSL quebraram placa com nome de Marielle Franco em comício de Wilson Witzel."

https://oglobo.globo.com/fato-ou-fake/e-fato-que-deputados-eleitos-pelo-psl-quebraram-placa-comnome-de-marielle-franco-em-comicio-de-wilson-witzel-23140096. Último acesso em: 25/02/2019, às $23 \mathrm{~h} 44$.

15 "Wilson Witzel reafirma: Snipers poderão abater quem portar fuzil". https://youtu.be/P6wDRLuOwZc. Último acesso em: 24/06/2019, às 16h43.
} 
pena a policiais em ações resultantes de medo, surpresa ou violenta emoção ${ }^{16}$. Assim sendo, policiais poderão não ser mais presos em flagrante diante das situações previstas pela proposta de Moro. Tais políticas, juntas, tornam matar "um assunto de alta precisão" (MBEMBE, 2018, p. 47), que pressupõe a elaboração de técnicas complexas de morte, inocentam os ceifadores de vida e tornam a população o seu alvo.

Mais adiante na entrevista citada, Witzel diz:

Wilson Witzel: Hoje mesmo teve um evento, eu não me lembro agora qual é o local. Repórter: Cidade de Deus.

Wilson Witzel: Cidade de Deus, estava um helicóptero de filmagem, tinham cinco elementos de fuzil. Ali, se você tem uma operação em que os nossos militares estão autorizados a realizar o abate, todos eles seriam eliminados.

O exercício do direito de matar recebe cada vez mais sofisticação, tornando mais eficaz e ágil sua atuação. Witzel, diferente da repórter que se refere aos indivíduos armados na favela como cidadãos, os chama de elementos, reforçando uma marcada distinção entre grupos, colocando os moradores da favela como incapazes de exercerem qualquer tipo de cidadania, os reduzindo a meros alvos e antagonistas de um iminente embate, exatamente o que o poder perante o direito de matar faz através da "lógica da sobrevivência” (MBEMBE, 2018, p. 62). Na mesma entrevista, Wilson Witzel, ex-juiz federal, faz a seguinte declaração:

Wilson Witzel: A lei é feita pra ser interpretada. Nós interpretamos a lei.

Repórter: E o senhor acha que vai, essa sua interpretação da lei vai conseguir passar?

Wilson Witzel: Eu digo sempre o seguinte, prefiro defender o policial no tribunal a ter que ir no funeral dele, ou de quem quer que seja. Então, nós vamos enfrentar o tribunal, vamos ter gente capacitada pra isso. Eu fiz uma dezena; dezena... centena de tribunais do júri como defensor público, e tribunal do júri é aquilo, é o povo julgando o povo. Se você consegue convencer que aquele acusado do crime é inocente, eles só precisam responder a uma pergunta (hoje o código do processo penal foi alterado): "culpado ou inocente?", como é no caso do júri americano. Então, o júri entendeu que ele atirou, matou e tá correto, acabou.

Mbembe denomina as fronteiras do Estado como colônias (2018, p. 34), similarmente aos territórios demarcados pelas potências europeias além de suas divisas geográficas. A visão do Estado é de que essas colônias "são habitadas por 'selvagens"”,

\footnotetext{
16 "Proposta de Moro prevê que juiz possa reduzir ou deixar de aplicar pena em casos de ações policiais resultantes de 'medo, surpresa ou violenta emoção'."

https://g1.globo.com/politica/noticia/2019/02/04/proposta-de-moro-preve-que-juiz-possa-reduzir-oudeixar-de-aplicar-pena-em-casos-de-acoes-policiais-resultantes-de-medo-surpresa-ou-violentaemocao.ghtml. Último acesso em: 25/02/2019, às $23 \mathrm{~h} 45$.
} 
e, como não se organizam de forma estatal, não formam um mundo humano. Podemos compreender, em um paralelo com as condições que vemos se desenvolverem no contexto brasileiro, e, ainda mais especialmente, no contexto fluminense, tais colônias como as favelas e as zonas periféricas, em que os índices de pobreza são mais elevados. Segundo Mbembe:

as colônias são zonas em que guerra e desordem, figuras internas e externas da política, ficam lado a lado ou se alternam. Como tal, as colônias são o local por excelência em que os controles e as garantias de ordem judicial podem ser suspensos - a zona em que a violência do estado de execução supostamente opera a serviço da 'civilização'. (2018, p. 35)

Um episódio que agrega ainda mais força à verdade do discurso que parte de Wilson Witzel é a intervenção militar que ocorreu durante o ano de 2018 no Rio de Janeiro, que reduziu o número de roubos, mas aumentou o número de mortes ${ }^{17}$ no Estado. O curioso da intervenção é que, apesar da proliferação de um discurso que condenava o Rio de Janeiro como uma cidade perigosa e que passava por uma situação de calamidade pública, ela sequer chegou a figurar na lista das 50 cidades mais perigosas do mundo ${ }^{18}$, das quais 17 são localizadas no Brasil. A tríplice poder, discurso e verdade atua aqui diretamente a favor da necropolítica, disseminando o terror e o medo através de discursos de verdade (que não são necessariamente verdades, mas são trabalhados para convencerem os indivíduos de que o são) e realizando ajustes nas leis que beneficiam o Estado em prol de atos contra as colônias. São os populares "mitos" vandalizando e corrompendo o status de heroísmo e salvação que a palavra possui.

\section{5) Considerações finais}

Entendendo a configuração de poder que se desenhou nas sociedades modernas, nota-se que o fascismo encontra profícuo campo de atuação em momentos de crises e fragilidade das estruturas democráticas. Como pontua Albright:

\footnotetext{
${ }^{17}$ Cf. "Cerimônia marca fïm da intervenção federal no RJ: 'Cumprimos a missão', diz general." https://g1.globo.com/rj/rio-de-janeiro/noticia/2018/12/27/cerimonia-encerra-intervencao-federal-naseguranca-do-rj.ghtml. Último acesso em: 25/02/2019, às 23 h45.

${ }^{18}$ Cf. "Estas são as 50 cidades mais violentas do mundo (e 17 estão no Brasil)." https://www.bbc.com/portuguese/brasil-43309946. Último acesso em: 25/02/2019, às 23h45.
} 
É assim que os tentáculos do fascismo se espalham por dentro de uma democracia. Enquanto uma monarquia ou uma ditadura militar são impostas à sociedade de cima para baixo, a energia do fascismo é alimentada por homens e mulheres abalados por uma guerra perdida, um emprego perdido, uma lembrança de humilhação ou a sensação de que seu país vai de mal a pior. Quanto mais dolorosa for a origem da mágoa, mais fácil é para um líder fascista ganhar seguidores ao oferecer a expectativa de renovação ou prometer restituir-lhes o que perderam. (ALBRIGHT; WOODWARD, 2018, p. 17)

Em meio a seu discurso, Jair Bolsonaro arrematou uma gama de admiradores que confiaram a ele o papel de redentor, pois, assim como nas guerras, em que "o tema da famosa batalha da manhã do dia seguinte que vai afinal inverter as forças e que, dos vencidos seculares, vai fazer enfim vencedores" ele "pôde se articular com base em uma grande mitologia" (FOUCAULT, 1999, p. 66). Com o Brasil estagnado em uma intensa crise sócio-político-econômica desde 2014, segundo informações que circulam na grande mídia ${ }^{19}$, a destituição de Dilma Rousseff de seu cargo presidencial, somada à condenação do presidente Luiz Inácio Lula da Silva e à série de escândalos que a Lava Jato $^{20}$ trazia à tona com suas investigações, Bolsonaro se tornou um mito que traria consigo soluções que colocariam o Brasil enfim nos eixos. Porém, em alguns meses de posse de seu mandato, o que vemos é seu discurso seguir gerando segregação, alimentando o terror e promovendo a violência.

Ao dizer que temos fascismo na cabeça, Foucault (1999, p. 35) atenta para a corruptividade que abarca o ser humano (esta não é um gene ou uma característica inata à bios, mas sim um componente socialmente adquirido) e para os processos de socialização aos quais estamos todos submetidos. Essa é uma chave de leitura fundamental para permitir a compreensão da questão que arrebata a todos os opositores do atual governo: por que o Brasil autoriza tão passivamente discursos que, por tantos aspectos, podem ser comparados a discursos fascistas?

Os indivíduos refletem o desejo da soberania em seu cotidiano, desejo esse disseminado em rede, atingindo a todos e não deixando um único sujeito imune de seus efeitos. Parece ser impossível, enquanto parte de um corpo social, não estar inserido sob a esfera do poder. Ele está em todos os lugares, não nos lembrando de sua existência, mas

\footnotetext{
${ }^{19} \mathrm{Cf}$. "Como o Brasil entrou, sozinho, na pior crise da história". https://epoca.globo.com/ideias/noticia/2016/04/como-o-brasil-entrou-sozinho-na-pior-crise-dahistoria.html. Último acesso em: 25/02/2019, às $23 \mathrm{~h} 46$.

${ }^{20}$ A Lava Jato é uma operação comandada pela polícia federal que apura crimes de corrupção. Revelando esquemas criminosos envolvendo a Petrobras, teve início em 2009 e é considerada a maior investigação de lavagem de dinheiro da história do Brasil.
} 
nos condicionando a um comportamento que compactua diretamente com sua eficácia. Mas então, se não é possível se livrar do poder, o que é possível fazer? O que tange ao alcance de nossa possibilidade é, insistentemente, realizar o exercício de limpar a poeira que encobre nossos olhos e borra as nossas convicções, cuidar de nossos ouvidos para não se deixarem seduzir por todo e qualquer discurso de verdade de cunho fascista (e, mais ainda, saber reconhecê-los), treinar nossa boca para rebater e condenar tais discursos, e, sempre que exequível, tomar posse de nossos corpos, ainda que estejam operando em função de uma força maior que os manipula e repreende.

Neste ponto final do trabalho, retomamos uma de nossas perguntas-guia: "quais vidas importam?”. A resposta varia de acordo com a ótica a partir da qual decide-se responder. Com as lentes da biopolítica, diríamos que as vidas que importam são aquelas passíveis de produzir esforço físico, de serem exploradas, de fazerem girar as engrenagens da economia através do trabalho braçal. Já para a necropolítica, são aquelas que detêm o poder econômico, que estão no topo da pirâmide hierárquica que distribui e organiza nossa sociedade entre os mais ricos e os mais pobres. Mas, como já apontado, outra pergunta se volta como emergente: “quais vidas não importam?”. Pela visão do poder, são vidas que atrapalham o seu funcionamento, que, diante da ação da soberania, obstruem seus planos de devastação e surgem como empecilhos de avanço. Dentro desta perspectiva, podemos mencionar - apenas a título de exemplo, dentre inúmeras outras também levantadas nesta pesquisa - a vida dos citados quilombolas e da ex-vereadora Marielle Franco como as que não necessitam de cuidado, que podem ser atiradas no limbo do extermínio. O poder não está deixando de ser o direito de fazer viver e voltando a ser o direito de fazer morrer - mesmo porque nunca deixou de ter sua função assassina; está apenas, cada vez mais, refinando suas táticas de morte, tornando-as cada vez mais competentes e produtivas. Não há espaço para o retorno da teoria da soberania, pois sua atuação é muito obsoleta mediante o progresso que o poder conquistou perante seu novo formato.

A política do medo e do terror implementadas e defendidas pelo atual presidente do Brasil, junto ao atual governador do Rio de Janeiro e a tantas outras figuras políticas que assombram o cenário político contemporâneo, garantem a soberania e estão em constante dependência de práticas necropolíticas. Elas são reais e se apresentam cotidianamente na forma de execuções exercidas nas periferias da cidade e do país, às 
vezes aplaudidas e comemoradas pelos governantes ${ }^{21}$. Ainda pior do que a consciência de que estamos submetidos ao poder de um Estado que produz um discurso de morte é estar submetido ao poder de um Estado que se orgulha de sê-lo.

A partir dos paralelos aqui traçados, as falas e ações apresentadas, além de outras sobre as quais não pudemos nos debruçar, produzidas pelo presidente Jair Bolsonaro e pelo governador Wilson Witzel, refletem a forma como o poder e a necropolítica operam: em grande consonância com regimes antidemocráticos que ecoam práticas fascistas. Muito mais do que apenas apontar adjetivações de modo ofensivo, buscamos com esta pesquisa suscitar reflexões e provocações em torno dos mecanismos que se desenvolvem por trás das faces de execução do poder pela extrema direita brasileira, que, não buscando desvencilhar-se de tais acusações, segue oferecendo material para os que traçam linhas entre suas ações e postulados e o campo semântico do fascismo, aprofundando as tentativas de buscar circunstâncias que sustentem o uso do termo.

\section{Referências}

ALBRIGHT, Madeleine; WOODWARD, Bill. Fascismo: um alerta. Tradução de Jaime Biaggio. São Paulo: Planeta, 2018.

ALMEIDA, Marco Rodrigo. Afinal, Jair Bolsonaro é ou não é fascista? In: Folha de São Paulo. 21 de outubro de 2018 Disponível em: https://www1.folha.uol.com.br/ilustrissima/2018/10/afinal-jair-bolsonaro-e-ou-nao-efascista.shtml. Acesso em 06 de dez. de 2018 às $21 \mathrm{~h} 32$.

BAKHTIN, Mikhail. Marxismo e filosofia da linguagem. $7^{a}$ ed. Tradução de Michel Lahud e Yara Frateschi Vieira. São Paulo: Hucitec, 1995.

ECO, Umberto. O Fascismo eterno. $2^{\mathrm{a}}$ edição. Tradução de Eliana Aguiar. Rio de Janeiro: Record, 2019.

FINCHELSTEIN, Frederico. Del fascismo al populismo en la historia. $1^{\text {a }}$ edição. Tradução de Alan Pauls. Nova Iorque: Penguin Ramdim House, 2019

FOUCAULT, Michel. Microfísica do poder. Organização e tradução de Roberto Machado. Rio de Janeiro: Edições Graal, 1979.

Em defesa da sociedade: curso no Collège de France (1975-1976). São Paulo: Martins Fontes, 1999.

MBEMBE, Achille. Necropolítica. São Paulo: N1 Edições, 2018.

\footnotetext{
${ }^{21}$ Cf. "Parentes falam em execução no Fallet; governador elogia policiais". https://globoplay.globo.com/v/7383828/. Último acesso em 10/04/2019 às 10h58.
} 
NOVAES, Marina. 'O que é fascismo?': a maior dúvida dos brasileiros em 2018, segundo o Google. El País. 13 de dezembro de 2018. Disponível em: https://brasil.elpais.com/brasil/2018/12/12/politica/1544636164_055761.html. Acesso em 19 de fev. de 2019 às 13 h53.

ORWELL, George. O que é fascismo? E outros ensaios. São Paulo: Companhia das Letras, 2017.

REICH, Wilhelm. Psicologia de massas do fascismo. $2^{a}$ edição. Tradução de Maria da Graça M. Macedo. São Paulo: Martins Fontes, 1998.

\title{
LA ASCENSIÓN DE UN TÉRMINO: FASCISMO, NECROPOLÍTICA Y EL ACTUAL CONTEXTO POLÍTICO BRASILEÑO
}

\begin{abstract}
Resumen
El término fascismo fue objeto de ampla búsqueda en las herramientas online de investigación en el año de 2018 en función de las elecciones, que han creado una intensa arena de polarización política. Su asociación se daba especialmente al candidato que hoy ejerce la presidencia del país, Jair Bolsonaro. En este artículo, planteamos hipótesis que sostienen la necesidad de recorrer a la palabra fascismo para definir una figura política, trayendo a colación relaciones de poder, que concretanse a través de la biopolítica (FOUCAULT, 1999) y de la necropolítica (MBEMBE, 2018), consolidando prácticas de vida y muerte y discursos de verdad.
\end{abstract}

\section{Palabras clave}

Fascismo. Necropolítica. Poder. Jair Bolsonaro. 